\author{
Adam Płachciak \\ Wrocław University of Economics \\ Faculty of Economy \\ Management and Tourism in Jelenia Góra \\ e-mail: adam.plachciak@ue.wroc.pl
}

\title{
Moral dilemmas of the development of postmodern societies"
}

\begin{abstract}
The aim of the article is to present tensions that occur in social, cultural, political, and technological spheres as a result of the development of postmodern societies. The changes that have been taking place in those areas involve, along with unquestionable benefits, a type of risk which, without any moral reflection, can cause a serious global crisis. The postmodern times should be understood as a continuation of the modern formation where all typical features of modernism take a more radical form. The postmodern specific style of life is characterised by uncertainty, the unpredictability of the future, as well as a decline of traditional values and morals. Moreover, the present postmodern tendencies in the area of morals can hinder the right course of development of society, economy and ecology.
\end{abstract}

Keywords: postmodernism, economic development, post-modern societies

JEL Classification: Q01, Z1

\footnotetext{
* The article is an updated version of the paper published in Polish in the Annales. Ethics in Economic Life, 11(1), 193-199.
} 


\section{Introduction}

One of the most important topics of recent years emerging in discussions of representatives of social sciences has been the issue of the pace of development and changes occurring in contemporary society. The popularity of concepts bearing the prefix post, e.g.: postmodernism or post-modernity, is a manifestation of the ongoing transformations in the cultural, social, political, economic and technological sphere in the countries of the Rich North. The aforementioned terms were used, mainly in the 1980s and 1990s, in an effort to describe the social directives of late capitalism. These concepts are, however, incorrectly treated as synonyms.

Postmodernism refers in fact to criticism in the field of literature, art or architecture. In this context, it means aesthetics that breaks with the modernist avantgarde, promoting more popular means of expression, directed more towards the embrace of eclecticism and the use of pastiche (Kowalska, 1997, p. 5). The term was used as early as in the 1930s by Federico de Onis in order to express his disapproval of contemporary poetry of modernism. ${ }^{1}$ The main features of postmodern art include the blurring of the boundaries between an artistic work and the aesthetics of everyday life, the disappearance of the previously existing division between high and mass culture, the popularity of superficiality, the decrease in the importance of the imperative of originality, and the assumption that art can only be an imitation or a modification of earlier works.

Post-modernity, however, is not a response to the emerging impasse of artistic modernism but instead refers to the crisis of modernity as a civilisation project. However, it is not a complete departure from the values of the modern era. Freedom of choice, diversity, and the possibility of expressing criticism were characteristics of modernity which remained in post-modernity. Post-modernity stands in opposition to the idea of a unified and standardised culture typical of modernity, which is a joint creation of all representatives of the human species. In place of modern tendencies to build a unified identity, the concept of irreducible differences in the area of interests, beliefs and values forming a background for interpersonal relations is introduced. The description of social reality indicates a clear lack of a unified vision of the world and a breakdown of "great narratives" that were meant to give meaning to and set a direction of historical development (Bauman, 1999, p. 353). The transition from deprivation values to post-materialist values (cf. Inglehart, 2005, pp. 334-348) among which the ideology of consumerism plays a significant role, is becoming a clearly visible feature of postmodern conditions.

\footnotetext{
${ }^{1}$ The publication of the work of Robert Venturi in 1972 entitled Learning from Las Vegas, which in a spectacular way presents the demolition of a modernist building in Saint Louis in the same year, is seen as a breakthrough moment in the field of architecture. Examples of postmodernism manifested in music include pieces of John Cage, Philip Glass, and Terry Riley, while in the field of novel writingworks by John Barth, Alain Robbe-Grillet or Thomas Pynchon, and in the filmmaking-productions of Jean-Luc Godard, David Lynch and others.
} 


\section{Postmodern division of the world}

Postmodern society is not particularly interested in the recruitment of either a massive industrial labour force or a conscripted army, but instead needs its members as consumers (Bauman, 2000, p. 95). The way in which citizens of this society are shaped is subordinated to omnipresent consumption. It is a kind of expression of human existence defining a specific human identity. The world that revolves around consumption is governed by temptations, growing desires and fleeting cravings. There is no mean value to which one could relate seeking uniform values that give meaning to human life. The main virtue of consumer society is the ability to respond to an emerging opportunity and to arouse the desire to achieve new, previously unknown sensations (Bauman, 2006, p. 119).

Contrary to appearances, consumerist society aims at assimilating individual groups of people into certain wholes. Post-modernity is even called the age of neotribalism. A desire to create new communities or tribes for various ethnic, racial and political groups emerges. Each of these communities seeks acceptance from other communities, as well as from the society as a whole. An example of such a need for recognition may be the popularity of consumer niches, gathering sets of subcultures around a particular type of music, model of means of transport (i.e. a motorcycle, a car, a yacht, a water scooter or a bicycle), form of spending free time or sophisticated clothing (Wątroba, 2006, p. 33). In this case, consumption becomes an important element in shaping the social bond. Nevertheless, the tolerance characteristic of postmodernity does not necessarily lead to group solidarity, as it is easily eroded by the egocentrism of rich people (Wątroba, 2006, p. 33), which continues to deepen the division into those who have easy access to socially valued goods and those who are marginalised.

The social impairment that occurs in the countries of the Rich North is becoming more and more acute and it impacts the populations beyond the small groups within local communities. Data from 1990 included in The New England Journal of Medicine indicate that that in the 35-55 age group, the AfricanAmerican death rate is 2.3 times higher than the corresponding rate for the white population in the same country, and that only half of this difference can be explained by purely economic determinants (quoted after Sen, 2000, p. 137). The phenomenon of intra-group diversity is to a large extent also dependent on factors that create a given social environment, such as a shortage of medical facilities, violence prevailing in large cities, a lack of social welfare, etc. (quoted after: Sen, 2000, p. 137). Political problems associated with the administration of health care and disparities in social welfare can seriously impair individuals and create social inequalities, even when the personal income of people is not low compared to international standards.

The postmodern division of the world also runs along the line which is determined by the degree of human mobility in space. Only individuals that maintain a certain level of consumption allowing them to "publicly show themselves without embarrassment" have an unquestioned freedom of changing their place of 
residence. They can always afford to leave famine and disease-threatened areas of the world, while those who cannot afford such a relocation are left behind. However, this does not apply only to third world countries. In the centres of many western metropolises, there is an invisible demarcation line which their inhabitants are not likely to cross. The experiences of people living on both sides of this boundary are so different that if they were to meet and exchange a few sentences, they probably would not know what to talk about.

Postmodern society is divided into two worlds. In the affluent portions of the world, an individual is realistically and virtually mobile without hindrance in time and space. This world is cosmopolitan, extraterritorial, managed by business and cultural managers. In the less privileged segments, the individuals are limited by local ties demanding their passive acceptance of imposed changes. This separation becomes acuter as the mass media magnify the differences making the distant realities closer to home. An abundance of time is the common element in both segments of the world. In the world of those that have, its consequence is boredom, in the world on the have-nots - frustration and aggression. However, the postmodern times do not have to generate mutual avoidance and intra-group separation; they can also be a plane for seeking a new identity.

\section{The world of generated risk}

The symptomatic feature of postmodern times is the emergence of new forms of risk. Uncertainty, threats and accidents have accompanied man since the dawn of history, but the emergence of the post-industrial civilisation, the goal of which is to make practically all areas of human life to be technology driven, is associated, apart from undisputed benefits, with a dose of alarming risk. Currently, not all people realise it or are able to assess the present or potential growing threats. In the postmodern era, which Ulrich Beck (2004) calls directly the era of risk society (Risikogesellschaft), a new quality of risk emerges. The fear and apprehension coming to the fore are not related to threats posed by the forces of nature, but instead are a consequence and a price of civic and technical progress.

The risk situation appears not only as a result of decision making but has a somewhat broader philosophical and historical context. It turns out that the Enlightenment project of human domination over nature has not been entirely possible to realise. The conviction that, thanks to the unique predispositions of human reason in the field of science and technology, it is possible to master all irrational elements of nature that could jeopardise human safety and well-being has been an illusion (Kiepas, 1999a, p. 58). This conviction has led to the belief in unlimited possibilities of the instrumental reason, the intention of which is to achieve world domination (Horkheimer \& Adorno, 1994, p. 19). The more man desires to dominate nature, the more it escapes man's control, which usually leads to the activation of a destructive potential, at least equally powerful as the desire to achieve well-being and safety. 
In postmodern society - as Anthony Giddens observes - the risk profile changes significantly, in the objective sense, understood as a global expansion of growing threats, as well as in the subjective sense, indicating the increasing perception and human awareness in the face of emerging threats (Giddens, 2006, pp. 150-197). Global risk expansion affects millions of people, regardless of ethnic or national affiliations, and the extent of its consequences is usually found post factum, i.e. after the explosion of the nuclear reactor in Chernobyl, after the leak of toxic substances from the Union Carbide chemical plant in Bhopal in India, after the emergence of the AIDS epidemic in Africa, after the greenhouse effect and climate change, and after the announcement of the news about the crash on stock exchanges. Such risks are universal and threaten both the rich and the poor, politicians and ordinary citizens, show business celebrities and social outcasts indiscriminately. No one is safe from such risks as these appear all over the world and affects everyone. It is frightening, however, that global risk expansion, and especially its effects, are still far beyond control not only of individuals but also of experts and even entire organisations.

In the subjective dimension, the new risk profile is a result of several reasons that cause greater perception and awareness of threats. Undoubtedly, the mass media play an important role in this respect, especially television that thrives on catastrophes, accidents, epidemics and other tragic events to increase its commercial attractiveness. The growing awareness of risk in the postmodern world is also closely related to the disappearance of psychological remedies, i.e. defence mechanisms referring to magical procedures or religious faith, characteristic of traditional societies. Secularisation of the Western civilisation has produced a lonely man left to his own devices having to face life threats. The source of growing awareness of the perceived dangers is also the increasingly common helplessness of highly educated technical experts and medical professionals who have lost social trust as a result of media coverage of their failures.

The belief about the emergence of risk generated in the postmodern times should prompt us to carry out an effective reflection on the need to anticipate, forecast, evaluate, control and prevent emerging threats and dangers that cannot be ignored when the quality of life not only of current but also future human generations is at stake. Technology, which is one of the main risk generators, cannot be an axiologically neutral system, as not all effects of its use and dissemination can be associated with the noblest intentions on the part of technology deploying entities.

\section{Opacity of social situations}

Postmodern society is characterised by significant opacity, fluidity and uncertainty of social situations in which modern man has come to live. No-one questions the fact that the present diversity of values and interests of individuals as well as entire social groups contributes to the disappearance of universally accepted patterns and schemes coordinating human activities. The essence of postmodern times is 
the heterogeneity of numerous discourses and the diversity of language games that create the social world. Reality is like one big text that can only be interpreted, it is not possible to ever formulate general laws governing the world, as in the opinion of postmodernists there are no such laws. In other words, the world does not exist by itself and independently of the human process of cognition; it is actually a product of constant interpretation and reinterpretation. What seems to be a permanent fact, an indisputable method, is only a cultural creation with a limited scope of existence in both historical and geographical sense. The postmodern man is entangled in the constant process of demystification and deconstruction, forcing him to be suspicious of all rules, norms and systems, even those he himself follows and those that he wants to create. In life, man goes through subsequent stages of "disenchanting the world" which deprive him of illusions, but always condemn him to some other kind of game. The aim of this game is not actually finishing the work begun but continuous fun, art, performance (Borkowski, 2003, p. 18).

Uncertainty and a sense of helplessness are the most common terms by which interpersonal relations are described in the most developed and wealthiest societies in the world. The following concepts express the feelings experienced in the postmodern times: 1) impermanence - of social positions and human rights; 2) instability — of material goods and means of subsistence; 3) security threatsboth to personal security and security of a given community, neighbourhood and country (Bauman, 2006, p. 249). A significant feature of present times is a lack of predictable relationship with sources of livelihood, especially with their most important aspect, i.e. a decent job and permanent employment. In highly developed countries, despite many optimistic promises of politicians about creating new jobs, unemployment is beginning to take on a "structural" character (Rifkin, 2003). Technological progress, apart from all its benefits, promises a drop rather than an increase in employment. Today, a secure job in a stable company seems like a dream. In postmodern societies with their changing labour markets, everybody is vulnerable to a loss of employment, although not equally, as the bestqualified employees are still the most sought after, but they too cannot be sure of their professional security. "No-one therefore"-according to Zygmunt Bauman (2006, p. 250) - "can feel irreplaceable - not those who have been fired or those whose job it is to do the firing."

In the face of long-lasting lack of a sense of security, there emerges a tempting desire to achieve immediate satisfaction from the tasks undertaken. Postponing fulfilment for later has lost its appeal. No-one can be sure that attitudes and products that are trendy at the moment will not become a subject of mockery and jokes soon. Man must be aware that his strengths can change in the blink of an eye into his weakness.

Opaque and uncertain socio-economic situations gradually make people accustomed to treating life as a conglomerate of disposable things. The world seems to be built of components that are not repaired but replaced.

In the world where a reflection on the future is absolutely pointless, as the future appears as something misty and vague, planning towards distant goals and sacrificing one's self-interest in their name do not seem as reasonable actions for 
representatives of postmodern society. The word "now" is the key to the implementation of life strategies, regardless of what these strategies concern and what their results are. Permanent obligations change into fixed-term contracts. Interpersonal ties and relationships are already treated as consumer goods. As in the market, the goods sold are offered for a "trial period", accompanied by the assurance that the customer receives a cash refund in the absence of full satisfaction with the purchased product.

The postmodern panorama of societies is an intricate mosaic of subcultures of tastes, attitudes and values, many of which have an ephemeral life. Impermanence, fluidity and opacity of social situations in the present world do not paint an optimistic picture, especially for those groups of people that have been marginalised as a result of current modernisation processes. Living one's life among many competing lifestyles, without solid and reliable guarantees of their justification, may prove to be extremely dangerous in the long run.

\section{Conclusions}

Due to the threats emerging in the postmodern times, it seems necessary to emphasise the ethics of human activity. Separation of various areas of human activity from morality is one of the causes of risk characteristic of contemporary culture. The challenges faced by mankind today create a new situation for ethics, different from what existed in the modern times. Postmodern ethics seems to stand out not so much because it concerns problems different from those that society of modern times faced, but rather because it has a new way of perceiving and interpreting these problems. Post-modernity in the axiological sphere is defined by the following features: 1) morality is aporetic; 2) moral principles cannot be promulgated; 3) moral phenomena are inherently irrational and people constituting their subjects are ambiguous (Kiepas, 1999b, pp. 197-198).

The search and need for new ethical paradigms are evident. Modern technology enables man to act with such a huge time-space scope and consequences that the framework of an individualist and traditional ethics seems insufficient. It is necessary to make a decisive step towards universal ethics, and it seems particularly important in this respect to see the role and significance of the principle of responsibility. The emphasis on responsibility, which is an integral part of being human in the world, is a measure of social risk awareness. The disappearance of a clear, transparent and easily formulated diagnosis defining the attitude of man to the world usually leads to the emergence of risk situations. Political practice, however, is still lagging behind the intellectual thought and alarmist voices of experts. Rescue operations so far still have a local scope. These limitations are often a result of the scarcity of funds allocated for this purpose, and sometimes they are just a consequence of the lack of interest on the part of the main strategists of the global economy and socio-political life. 


\section{References}

Bauman, Z. (1999). Nowoczesność i ponowoczesność. In Encyklopedia socjologii (Vol. 2). Warszawa: Oficyna Naukowa.

Bauman, Z. (2000). Globalizacja. Warszawa: Państwowy Instytut Wydawniczy.

Bauman, Z. (2006). Ptynna nowoczesność. Kraków: Wydawnictwo Literackie.

Beck, U. (2004). Spoleczeństwo ryzyka. W drodze do innej nowoczesności. Warszawa: Wydawnictwo Naukowe Scholar.

Borkowski, R. (2003). Globalizacja, cywilizacja, ponowoczesność. In R. Borkowski (Ed.), Globalopolis. Kosmiczna wioska - szanse $i$ zagrożenia. Warszawa: Instytut Wydawniczy "PAX".

Giddens, A. (2006). Nowoczesność i tożsamość. “Ja” i społeczeństwo w epoce późnej nowoczesności. Warszawa: Wydawnictwo Naukowe PWN.

Horkheimer, M., \& Adorno, T. W. (1994). Dialektyka oświecenia. Warszawa: Wydawnictwo Instytutu Filozofii i Socjologii Polskiej Akademii Nauk.

Inglehart, R. (2005). Pojawienie się wartości postmaterialistycznych. In P. Sztompka, \& M. Kucia (Eds.), Socjologia: lektury. Kraków: Wydawnictwo Znak.

Kiepas, A. (1999a). Etyka a ryzyko działań człowieka w środowisku. In M. Dołęga, W. Czartoszewski (Eds.), Ochrona środowiska w filozofii i teologii. Warszawa: Wydawnictwo Akademii Teologii Katolickiej w Warszawie.

Kiepas, A. (1999b). Ryzyko jako problem ekofilozofii. In A. Latawiec, \& G. Bugajak (Eds.), Między filozofia przyrody a ekofilozofią. Warszawa: Wydawnictwo Uniwersytetu Kardynała Stefana Wyszyńskiego.

Kowalska, M. (1997). Mała opowieść tłumacza. In J.-F. Lyotard, Kondycja ponowoczesna (pp. 5-17). Warszawa: Fundacja Aletheia.

Płachciak, A. (2008). Moralne dylematy rozwoju społeczeństw ponowoczesnych. Annales. Ethics in Economic Life, 11(1), 193-199.

Rifkin, J. (2003). Koniec pracy - schytek sity roboczej na świecie i początek ery postrynkowej. Wrocław: Wydawnictwo Dolnośląskie.

Sen, A. (2000). Nierówności. Dalsze rozważania. Kraków: Społeczny Instytut Wydawniczy Znak.

Wątroba, W. (2006). Spoleczeństwo konsumpcyjne $w$ dobie globalizacji. Wrocław: Wydawnictwo Akademii Ekonomicznej im. Oskara Langego we Wrocławiu. 